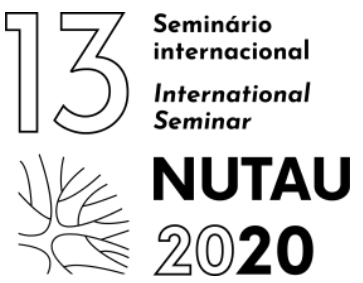

\title{
Cenários e tendências na gestão dos resíduos da arborização urbana
}

Adriana Maria Nolasco

Escola Superior de Agricultura Luiz de Queiroz / USP

Doutora em Ciências da Engenharia Ambiental, amnolasc@usp.br

\section{RESUMO}

Resíduos da arborização urbana são compostos por materiais madeireiros resultantes dos serviços de poda e supressão de árvores e arbustos com fins estéticos, funcionais e fitossanitários. São gerados em grande quantidade nas cidades brasileiras e destinados normalmente à disposição em aterros sanitários, compostagem e uso como fonte de energia. Também é prática comum o descarte em áreas irregulares e a queima à céu aberto, resultando em impactos ambientais negativos e problemas à saúde pública. Por outro lado, a diversidade de espécies, a grande quantidade disponível e sua dispersão em todo o território nacional, são fatores que favorecessem seu aproveitamento em produtos madeireiros de maior valor agregado. A Política Nacional de Resíduos Sólidos e o Novo Marco Legal do Saneamento Básico definem as responsabilidades dos geradores em relação ao gerenciamento dos resíduos e priorizam a adoção de modelos baseados na redução da geração e na valorização através de diferentes rotas tecnológicas, destinando aos aterros somente os rejeitos. Esse cenário aponta a necessidade urgente de desenvolvimento de novas alternativas de valorização dos resíduos verdes, baseadas em princípios da Economia Circular e da Agenda 2030 como o consumo regenerativo e a conservação do capital natural; a otimização do rendimento dos recursos com a recirculação dos materiais e o uso em cascata; e a inclusão social em empreendimentos inovadores e solidários.

Palavras-chave: valorização de resíduos, arborização urbana, manejo arbóreo, materiais madeireiros, Política Nacional de Resíduos Sólidos.

\begin{abstract}
Residues from urban afforestation are composed of wood materials resulting from pruning and suppression services for trees and shrubs for aesthetic, functional and phytosanitary purposes. They are generated in large quantities in Brazilian cities and are normally intended for disposal in landfills, composting and use as an energy source. It is also common practice to dispose of irregular areas and burning in the open, resulting in negative environmental impacts and problems to public health. On the other hand, the diversity of species, the large quantity available and its dispersion throughout the national territory, are factors that favor its use in wood products with higher added value. The National Solid Waste Policy and the New Legal Framework for Basic Sanitation define the responsibilities of generators in relation to waste management and prioritize the adoption of models based on the reduction of generation and recovery through different technological routes, destining only the waste. This scenario points to the urgent need to develop new alternatives for the valorization of green waste, based on the principles of Circular Economy and the 2030 Agenda such as regenerative consumption and the conservation of natural capital; the optimization of resource yields with the recirculation of materials and the cascade use; and social inclusion in innovative and supportive ventures.
\end{abstract}

Keywords: waste valorization, urban afforestation, tree management, wood materials, National Solid Waste Policy. 